\title{
Modeling Management Scenarios and the Effects of an Introduced Apex Predator on a Coastal Riverine Fish Community
}

\author{
William E. Pine III ${ }^{* 1}$ and Thomas J. KwaK \\ U.S. Geological Survey, North Carolina Cooperative Fish and Wildlife Research Unit, ${ }^{2}$ Campus Box 7617 , \\ North Carolina State University, Raleigh, North Carolina 27695, USA
}

\author{
JAMES A. Rice \\ Department of Zoology, Campus Box 7617, North Carolina State University, \\ Raleigh, North Carolina 27695, USA
}

\begin{abstract}
The flathead catfish Pylodictis olivaris, a carnivorous fish species native to most of the central interior basin of North America, has been introduced into at least 13 U.S. states and 1 Canadian province. Concurrent declines in abundance of native fishes have been reported in aquatic systems where flathead catfish have been introduced. To evaluate the potential impact of this invasive species on the native fish community we developed an ecosystem simulation model (including flathead catfish) based on empirical data collected from a North Carolina coastal river. The model results suggest that flathead catfish suppress native fish community biomass by $5-50 \%$ through both predatory and competitive interactions. However, our model suggests these reductions could be mitigated through sustained exploitation of flathead catfish by recreational or commercial fishers at rates equivalent to those for native flathead catfish populations (annual exploitation $=$ 6-25\%). These findings demonstrate the potential for using directed harvest of an invasive species to assist in restoring native communities.
\end{abstract}

The introduction and establishment of nonnative species is a widespread and poorly understood global phenomenon. While most species introductions fail or persist unnoticed (Williamson 1996), some lead to declines in the abundance or diversity of native species and occasionally to cascading negative ecosystem level effects that impact human populations (Folkerts 1999). The annual economic impact of the 50,000 nonnative species that have been introduced into the United States is about US $\$ 137$ billion (Pimentel et al. 2000), an amount nearly 13 times greater than the 2004 budget for the Department of Interior, the primary U.S. governmental agency charged with fish and wildlife conservation and management (USDOI 2005). This cost does not include the impacts of species that have been translocated within the United States and their potential effect (Pimentel et al. 2000).

Generalizations describing the biotic and abiotic characteristics that regulate the success or failure of an invasive species have been derived from field, experimental, and theoretical studies (Elton 1958;

\footnotetext{
* Corresponding author: billpine@ufl.edu

${ }^{1}$ Present address: Department of Fisheries and Aquatic Sciences, University of Florida, 7922 Northwest 71st Street, Gainesville, Florida 32653, USA.

${ }^{2}$ The Unit is jointly supported by North Carolina State University, North Carolina Wildlife Resources Commission, U.S. Geological Survey, and Wildlife Management Institute.
}

Received October 14, 2005; accepted August 11, 2006 Published online January 15, 2007
Williamson 1996), and the resulting body of literature describing invasive species is immense. Invading species encounter environmental (e.g., suitable habitat), biotic (e.g., competition), and demographic (e.g., reproductive traits) resistance that must be overcome to establish a self-sustaining population (Moyle and Light 1996a). Failure in any one of these areas usually leads to the invasion failing (as most do). However, in situations where invasive species have been purposefully introduced for food or recreation, humans have often selected species with desirable (to humans) physical traits (e.g., large size and palatable flesh) and introduced these species repeatedly into ecosystems that are vulnerable to invasion (e.g., highly disturbed or degraded systems) (Moyle and Light 1996b). This human intervention increases the likelihood of a successful invasion by circumventing many of the naturally existing invasion obstacles.

While perhaps not as captivating as introductions from regions outside of the United States, translocations of nonnative species within the country have had dramatic impacts on aquatic ecosystems. Community compositions in both coastal and inland aquatic ecosystems in the United States have been widely altered by species introductions. For example, two endemic Atlantic Slope fishes, striped bass Morone saxatilis and American shad Alosa sapidissima, were both introduced and established along the U. S. west coast in the 19th century, and largemouth bass Micropterus salmoides, which has a native range 
primarily in the Mississippi River valley and southern Atlantic Slope, is now found throughout North America and around the world ( $\mathrm{Li}$ and Moyle 1993; Nielsen 1993). While artificial range expansion of game fishes through stocking by management agencies is less common than it once was (e.g., Vander Zanden et al. 2004), it is clear that fish faunas across the continental United States have become more similar through widespread introductions of fish species intended to enhance food and sport fisheries (Rahel 2000). However, the effects of these species introductions are not fully understood and are rarely considered until after the introduced species has become established, greatly limiting management options.

The flathead catfish Pylodictis olivaris is a large piscivorous catfish native to most of the U.S. interior throughout the drainages of the Rio Grande, Mississippi, and Mobile rivers (Smith-Vaniz 1968; Jenkins and Burkhead 1994). Flathead catfish have been legally and illegally introduced into at least 13 U.S. states (primarily along the Atlantic Slope) and 1 Canadian province (Jackson 1999) usually in an effort to establish recreational fisheries. Within 15 years following their introduction into North Carolina (the only documented introduction is of 11 individuals), flathead catfish had expanded to a $200-\mathrm{km}$ reach of the Cape Fear River and have emerged as the dominant predator in the drainage basin (Guier et al. 1984).

Flathead catfish are widely prized throughout their native range as a trophy sport fish due to their large size (current world angling record, $56.4 \mathrm{~kg}$ ), fighting ability when hooked, and highly palatable flesh. These qualities support recreational and commercial fisheries throughout their native range and developing fisheries throughout their introduced range (Quinn 1993; Jackson 1999; Travnichek and Clemmons 1999). Unlike most other catfishes, flathead catfish are obligate carnivores and primarily piscivorous, and given their potential to reach large sizes, their feeding patterns have been widely studied to discern interactions with other fish species (Pine et al. 2005).

Swingle (1967) documented that flathead catfish greater than $254 \mathrm{~mm}$ total length "may compete with fishermen for fish of harvestable size" in ponds. Results from other diet studies, as well as widespread concern over declining populations of native fishes following flathead catfish introduction, have compelled the study of flathead catfish food habits in their introduced range (Guier et al. 1984; Ashley and Buff 1988; Quinn 1988; Thomas 1995). These studies generally document a decline in native fish populations (likely via predation) following introduction of flathead catfish. The species affected are usually native centrarchids and ictalurids, but other native fishes including the federally endangered razorback sucker Xyrauchen texanus in the San Pedro River, Arizona are thought to be threatened by flathead catfish introduction (Marsh and Brooks 1989).

We developed an ecosystem model that includes flathead catfish for a North Carolina coastal plain river based on empirical data from the system. Given the seemingly ever increasing global demand for fish products, the ability of humans to alter aquatic ecosystems through intensive fishing efforts (Jackson et al. 2001), the popularity of flathead catfish as a food fish in its native range (Jackson 1999), and the large recreational and commercial fisheries interest in North Carolina and other Atlantic Slope states, flathead catfish may be an excellent candidate species to promote for more intensive harvest. Flathead catfish harvest would provide a desired food product and may also help restore native ecosystems by reducing the biomass of an invasive species. We examined how manipulating exploitation rates of flathead catfish may affect their abundance and ecological role in structuring the native fish community. These simulations may prove useful in exploring management scenarios for established and newly introduced populations of flathead catfish and for understanding the ecological consequences of this and other introduced species.

\section{Methods}

Model design.-We developed an ecosystem simulation model based on Contentnea Creek $\left(35^{\circ} 20^{\prime} 03^{\prime \prime} \mathrm{N}\right.$, $77^{\circ} 22^{\prime} 73^{\prime \prime} \mathrm{W}$ ), a large tributary of the Neuse River in eastern North Carolina, using an Ecopath and Ecosim framework (Walters et al. 1997; Christensen et al. 2000). The initial model (Ecopath) is a mass balance of ecosystem production and losses of biomass for each component of an ecosystem over a given time period. Two key equations drive the models developed in Ecopath: the first describes biomass production in the ecosystem and the second describes energy balance for each group in the model (Christensen and Walters 2004). Balance is achieved when the sum of production and immigration is equal to predatory losses, nonpredatory mortality, harvest, and emigration. Because all variables are linked within a food web, changes in one variable are expressed as changes in other (often many) components of the web. Flow and linkages are established among different components of the food web model. A second model (Ecosim) simulates changes in the initial balanced steady-state of the food web (the Ecopath model) with altered exploitation rates, species interactions, environmental changes, or a combination of factors. Ecopath and Ecosim models have been used to examine links among producers, consumers, and harvesters in marine, freshwater, and 


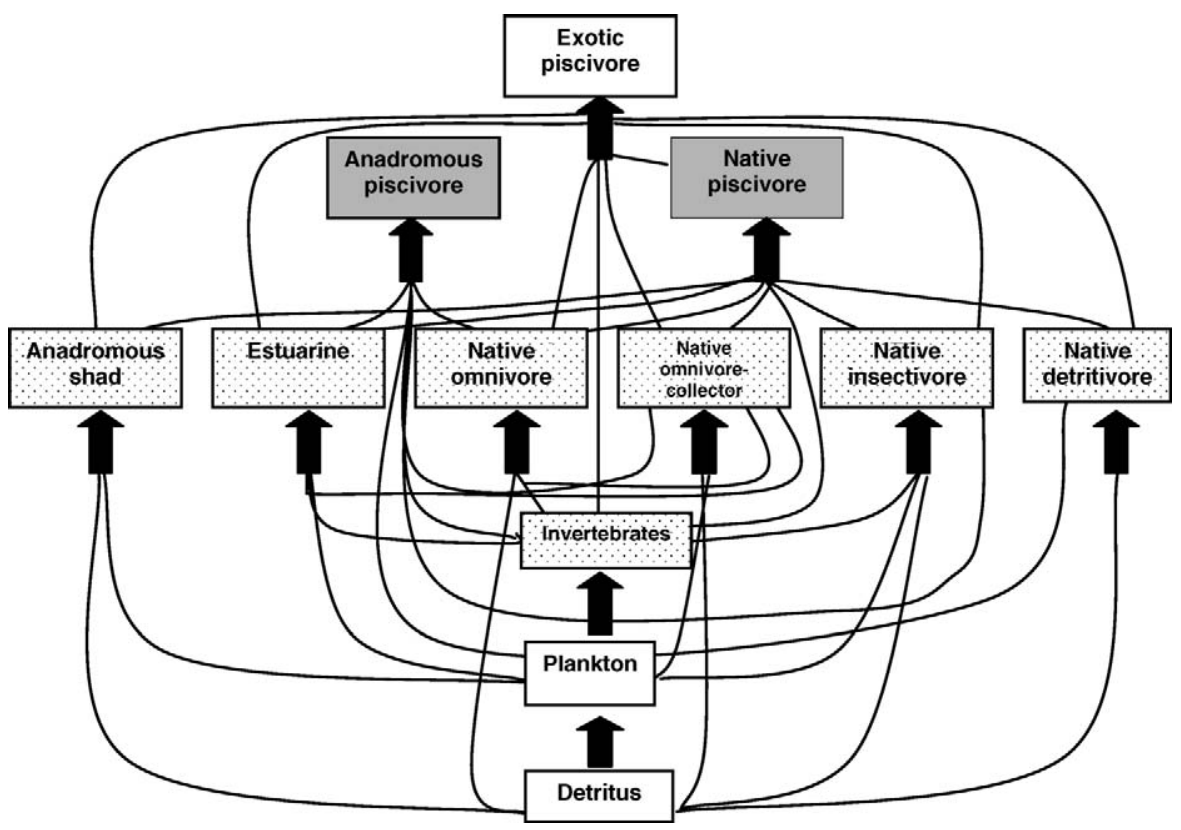

FIGURE 1.- Simplified food web diagram showing the linkages among functional groups in Contentnea Creek. The vertical position of each box indicates the approximate trophic level of that group, the lowest group being at the bottom. Light gray boxes represent functional groups that primarily compete with flathead catfish (exotic piscivore group) for available food resources; boxes with stippling represent groups consumed by flathead catfish.

terrestrial ecosystems ( $>150$ publications; e.g., Krebs et al. 2003; Christensen and Walters 2004). Explicit details of the modeling approach are published elsewhere (Walters et al. 1997; Christensen et al. 2000; Kitchell et al. 2000; Christensen and Walters 2004). Software is available for download through the World Wide Web (www.ecopath.org) and model parameter values are listed in Table A.1 in the appendix.

Our model was developed from empirical data from North Carolina coastal plain rivers. Most field sampling occurred during spring through early fall of 2000-2003 when warm water temperatures were conducive to sampling both introduced and native fishes (Pine 2003). Our model was composed of 12 functional groups: 8 fish groups, 1 invertebrate group, 1 plankton group, and 1 detritus group (Figure 1; Table 1). Fish were grouped based on similar morphometric, feeding, and life history functional attributes (Table 1). For example, flathead catfish were placed in an exotic piscivore group while all darters (Percina and Etheostoma spp.) and Cyprinidae were placed in a single omnivore-collector group.

Model initialization required estimates for each functional group of habitat area used, as well as biomass $(B)$, the production : biomass ratio $(P: B)$, the consumption: biomass ratio $(Q: B)$, diet information, and biomass harvested. As much as possible this information was derived empirically for each functional group. For example, estimates of instantaneous mortality $(Z)$ were obtained for flathead catfish using catch-curve analysis (Kwak et al. 2006), while mortality estimates for other functional groups were calculated by dividing the annual production for each functional group by its biomass. Biomass for each fish functional group was estimated by first calculating the abundance for each individual species using a threepass removal method (Seber 1982). Removals were conducted along a 400-m section of river that represented the long-term fish monitoring site for the North Carolina Wildlife Resource Commission (NCWRC). River widths ranged from about 30 to 40 $\mathrm{m}$, river depths ranged from 0.4 to $2 \mathrm{~m}$, and the substrate composition was a mixture of sand, silt, and clay. We attempted to close each end of the sampling reach with block-nets but were unsuccessful in maintaining the nets in place during the entire sampling event due to water flow, leaf litter, and other debris. Removal samples were conducted using boat-mounted electrofishing with two boats equipped with identical electrofishing gear, each sampling along opposite banks of the river at a safe distance in an attempt to sample the entire width of the river as the boats moved downstream. Individual fish weights were measured in 
TABLE 1.- Species or family composition of each functional group included in the Ecopath model.

\begin{tabular}{|c|c|}
\hline Functional group & Species or family \\
\hline Exotic piscivore & Flathead catfish Pylodictis olivaris \\
\hline Native piscivore & $\begin{array}{l}\text { Black crappie } \\
\quad \text { Pomoxis nigromaculatus } \\
\text { Bowfin Amia calva } \\
\text { Chain pickerel Esox niger } \\
\text { Redfin pickerel Esox americanus } \\
\text { Largemouth bass } \\
\quad \text { Micropterus salmoides } \\
\text { Longnose gar Lepisosteus osseus }\end{array}$ \\
\hline Native anadromous piscivore & Striped bass Morone saxatilis \\
\hline Native omnivore & $\begin{array}{l}\text { Channel catfish Ictalurus punctatus } \\
\text { Creek chubsucker } \\
\text { Erimyzon oblongus }\end{array}$ \\
\hline Native omnivore—collector & $\begin{array}{l}\text { Eastern mudminnow } \\
\text { Umbra pygmaea } \\
\text { Eastern silvery minnow } \\
\text { Hybognathus regius } \\
\text { Pirate perch Aphredoderus sayanus } \\
\text { Satinfin shiner } \\
\text { Cyprinella analostana } \\
\text { Swallowtail shiner Notropis procne } \\
\text { Comely shiner Notropis amoenus } \\
\text { Sawcheek darter Etheostoma serrifer } \\
\text { Shield darter Percina peltata } \\
\text { Tessellated darter } \\
\text { Etheostoma olmstedi } \\
\text { Glassy darter Etheostoma vitreum }\end{array}$ \\
\hline Native insectivore & $\begin{array}{l}\text { Bluegill Lepomis macrochirus } \\
\text { Pumpkinseed Lepomis gibbosus } \\
\text { Redear sunfish Lepomis microlophus } \\
\text { Redbreast sunfish Lepomis auritus } \\
\text { Eastern mosquitofish } \\
\quad \text { Gambusia holbrooki }\end{array}$ \\
\hline Native detritivore & $\begin{array}{l}\text { Gizzard shad Dorosoma cepedianum } \\
\text { Shorthead redhorse } \\
\text { Moxostoma macrolepidotum } \\
\text { Silver redhorse Moxostoma anisurum }\end{array}$ \\
\hline Native estuarine & Hogchoker Trinectes maculatus \\
\hline Native anadromous omnivore & $\begin{array}{l}\text { American shad Alosa sapidissima } \\
\text { Hickory shad Alosa mediocris }\end{array}$ \\
\hline Invertebrates & $\begin{array}{l}\text { Crayfish (Cambaridae family) } \\
\text { Mayfly (Baetidae family) }\end{array}$ \\
\hline $\begin{array}{l}\text { Plankton } \\
\text { Detritus }\end{array}$ & \\
\hline
\end{tabular}

the field and the average weight was assigned to each species in the functional group. A weighted average (weighted by species abundance) was then used to calculate the mean biomass for that entire functional group. Capture histories from the removals were pooled within each functional group to develop a group-wide capture probability. This capture probability was then used to estimate abundance for the species with very low biomass whose abundance was not able to be estimated using removal methods (Pine 2003). Contentnea Creek supports spring runs of anadromous shad Alosa spp. and striped bass, which occurred before we sampled. For this modeling effort we only considered the sizes and densities of each genus collected during our sampling periods. Thus, only juvenile shad (a prey item) and resident striped bass (a predator found in low numbers, which does not return to the marine environment in a given year) are included in our model.

Removal population estimates were conducted in late spring and early fall; thus, approximate annual $P: B$ ratio values could be calculated by subtracting the biomass of a functional group in the fall from that group's biomass in the spring and dividing by the spring biomass. The $Q: B$ ratios for each species were calculated using the online estimator available through Fishbase (www.fishbase.org), which is based on equations provided by Pauly (1986) and Palomares and Pauly (1989). An average $Q: B$ for each functional group was then calculated using a weighted mean (by abundance of each species). Diet matrices were developed from empirical diet samples conducted in conjunction with this study (for flathead catfish, Pine et al. 2005) or from published reports (see Table A.2 in the appendix).

Exploitation rates for all fish species in Contentnea Creek are relatively low, primarily because of the remote location and limited river access. Harvest occurs for several species included in our model, primarily native sunfishes Lepomis spp., largemouth bass, striped bass, and flathead catfish. For modeling efforts we used an estimated annual biomass exploitation level $(u)$ for flathead catfish of $4 \%$ based on harvest rates of a group of fish radio-tagged as part of another aspect of this study (Kwak et al. 2004). Because of uncertainty associated with this exploitation rate we simulated a wide range of exploitation rates that span most potential rates for flathead catfish in this and other systems. Estimates of annual exploitation rates for native flathead catfish recreational fisheries in the Missouri River, Missouri, are $25 \%$ or greater (V. Travnichek, Missouri Department of Conservation, unpublished data) and in introduced populations in the Flint River, Georgia, are between 14 and 25\% (Quinn 1993). Combined with commercial harvest, total exploitation rates could be higher. Exploitation rates for all other species were derived from published estimates (Pine 2003).

Model application and scenarios.-After the introduction of an invasive species, resource management agencies frequently focus their efforts on eradication options for the invader. However, invasive species may become well established before management actions occur, and complete removal is rarely a viable option. Instead, resource management agencies may become interested in the impacts of the invasive species on native species and how manipulation of invasive species abundance might impact native populations. Because many fish species (including flathead catfish) represent a desirable food product, and fisheries 
management agencies, commercial fishing interests, and recreational anglers have a history of manipulating and exploiting fish populations, we used this model to evaluate how native fish communities would respond to varying reductions in flathead catfish populations as a result of intensive exploitation. We modeled changes in the native fish community biomass under a scenario that emulated the original introduction of flathead catfish in a coastal North Carolina river based on historical fish samples collected from the Cape Fear River using rotenone (Guier et al. 1984; Ashley and Buff 1988). These simulations were then compared with historical information as a measure of confidence in the Ecopath model's ability to simulate ecosystem behavior. We then used the Ecopath model to evaluate ecosystem response (measured as a change in biomass of native fish groups) to high rates of flathead catfish exploitation. This scenario was designed to simulate extirpation of flathead catfish from the system, as removal of an invasive species is often an initial management option considered in ecosystem restoration. Our third simulation examined how native fish communities may respond (as measured by a change in biomass) to sustained exploitation of flathead catfish across a range of exploitation rates similar to those found for native populations of flathead catfish.

Historical invasion analysis.-We used historical information on the introduction of flathead catfish in North Carolina in two ways: (1) to calibrate the initial introduced biomass of flathead catfish in the ecosystem, and (2) to assess our modeling approach through comparison with the predicted magnitude and rate of change of the response by the native fish community to the introduction of flathead catfish. The only documented release of flathead catfish into North Carolina waters was a single release of 11 individuals with a total weight of $107 \mathrm{~kg}$ into the Cape Fear River, a large North Carolina coastal plain river about $75 \mathrm{~km}$ southeast of Contentnea Creek (Guier et al. 1984). The source or date of the flathead catfish introduction in Contentnea Creek is not known. As a general assessment of our modeling approach we evaluated how early reports (Guier et al. 1984) of the rapid growth in the flathead catfish population and subsequent changes within the native fish community compare with the predictions of our model and observations by a NCWRC fishery biologist (K. Ashley, personal communication).

Because this model is based on an ecosystem that already contains flathead catfish, we first developed an approximation of what the ecosystem may have looked like in the absence of flathead catfish. This was accomplished by simulating very high flathead catfish exploitation rates (in effect removing flathead catfish from the system) and then allowing the simulated ecosystem without flathead catfish to reach equilibrium. This equilibrium then was compared with the limited historical information on native fish community composition before flathead catfish introduction as an indicator of model performance. We then simulated the original flathead catfish introduction and compared predicted changes in the native fish communities to observed historical changes in the native fish community.

Modeling the potential for ecosystem restoration.Common management responses to species introductions usually focus on whether the ecosystem can be restored to a previous state. We examined whether it is possible to turn back the clock and restore the ecosystem to a preinvasion state through the use of directed harvest of flathead catfish. We addressed this by examining how targeted harvest of flathead catfish could lead to changes in the native fish community. We used exploitation rates $(u)$ of $6 \%$ and $25 \%$ that are similar to the range of flathead catfish exploitation rates in native and introduced populations. Each of these exploitation rates was sustained for 10 years. The resiliency of both flathead catfish and native fish populations to increased flathead catfish exploitation then was examined by reducing exploitation to current rates and monitoring ecosystem response. Finally, we evaluated a maintenance control option where flathead catfish exploitation oscillates between a 5-year high exploitation period $(u=25 \%)$ and a reduced exploitation period $(u=6 \%)$ for 5 years. Again, simulated exploitation levels mimic actual rates for native populations of flathead catfish.

Flathead catfish eradication.-We examined the ecosystem response to an effort to eliminate flathead catfish by simulating intensive removal via simulated exploitation of $33 \%$ and $54 \%$ (approximately 10 and 20 times current levels) sustained for 10 years. Intensive exploitation then was stopped, and ecosystem response was monitored for 10 years as above. Additionally, long-term resiliency to intensive exploitation was evaluated by conducting the same eradication simulations, but monitoring the ecosystem for longer time periods, 50 years for the $u=33 \%$ and 100 years for the $u=54 \%$ scenario. These exploitation rates could be achieved through resource agency personnel targeting flathead catfish for removal by scientific sampling in conjunction with commercial and recreational fishing efforts.

\section{Results \\ Historical Invasion Analysis}

Our invasion simulation was initiated with the same introductory biomass as the original flathead catfish release into the Cape Fear River. This simulation 
resulted in declines in biomass of about $30 \%$ in the anadromous shad and native insectivore groups and about a $50 \%$ decline in the anadromous and native piscivore groups after reaching equilibrium (Figure 2). Biomass of other groups declined by about $5-15 \%$ with the exception of native detritivores, which increased by about $30 \%$ (Figure 2). In this invasion scenario flathead catfish were predicted to become the dominant apex piscivore by functional group biomass in less than 50 years.

\section{Modeling the Potential for Ecosystem Restoration}

Currently, the exploitation of flathead catfish in Contentnea Creek is low, about $4 \%$ per year. Our model predicted that reducing flathead catfish biomass by increasing exploitation rates to $6 \%$ would lead to about a $16 \%$ increase in biomass for most native fish groups in 10 years (Figure 3A, B). As exploitation rate increased, flathead catfish biomass declined and native fish biomass increased. At an increased exploitation level of $25 \%$ flathead catfish biomass was reduced by about $50 \%$, leading to increased population biomass of about $25-75 \%$ for native piscivores, native insectivores, anadromous piscivores, and estuarine species in less than 10 years following an increase in flathead catfish exploitation to $25 \%$ (Figure 3C, D). Other native fish groups including omnivores and omnivorecollectors also showed population biomass increases of 2-10\% while native detritivores showed population declines of about 20\% (Figure 3C). If higher fishing pressure was not sustained, the population biomass of all functional groups was predicted to return to that of preincrease fishing levels in less than 10 years.

\section{Eradication Efforts}

Simulated flathead catfish exploitation rates of more than $33 \%$ were not sustainable, and at this rate flathead catfish were nearly eliminated from the system by harvest. At 33\% exploitation, flathead catfish biomass was reduced by about $90 \%$ within 10 years and native detritivores declined by $24 \%$, while other native fish groups increased by 16-100\% (Figure 4A, B). A larger increase in flathead catfish exploitation (54\% exploitation) reduced flathead catfish biomass by about $95 \%$ within 5 years, nearly extirpating it from the system for at least 15 years (Figure 4C, D). This reduction in flathead catfish biomass resulted in the biomass declining by about $28 \%$ for native detritivores, an approximate doubling in biomass for native and anadromous piscivores, a $50 \%$ increase in biomass for native insectivores, anadromous shad, and estuarine species, and biomass increases of $5-15 \%$ for native omnivores and omnivore-collectors (Figure 4C, D).

\section{Resiliency to Exploitation}

Our simulations demonstrate the resiliency of flathead catfish to exploitation. If exploitation ranges from $6 \%$ to $33 \%$ for a period of 10 years and then falls to current levels (about 4\%), flathead catfish populations will return to their initial biomass within 5-50 years and subsequently reduce native fish populations to pre-exploitation levels (Figures 3-5). Under a modeling scenario of very high exploitation (54\%) sustained for 10 years (e.g., from a subsidized commercial fishery), the flathead catfish population was predicted to crash ( $0.01 \%$ of original biomass), yet recover from this intense harvest and return to original levels in about 80 years (Figure 5).

The maintenance control management scenario (alternating 5-year periods of high and low exploitation) dampened the observed resiliency to decreased fishing pressure and maintained relatively high positive increases in native fish biomass (Figure 6). As previously predicted, the greatest change in native fish abundance came when flathead catfish abundance was lowest (periods where $u=25 \%$ ). However, even when fishing harvest was reduced $(u=6 \%)$ following 5 years of high exploitation, biomass of most native fish remained much higher than it would have been at the low fishing rate alone. Average biomass response during the maintenance control simulations for recreationally important species was highest for native and anadromous piscivores (approximately 70\% increase each), followed by native insectivores and anadromous shad (approximately 30\% increase each). Average flathead catfish biomass reductions were approximately $70 \%$ after 20 years of alternating high and low exploitation. Even at reduced biomass levels, if intensive fishing for flathead catfish was halted, flathead catfish and native fish populations would eventually return to premaintenance control levels.

\section{Discussion}

The results of this modeling exercise suggest that reduction of flathead catfish biomass by exploitation may allow an increase in the biomass of a variety of native fish groups. Native apex predators in our model (native and anadromous piscivore groups) showed the greatest response to the modeled initial introduction and reduction in flathead catfish populations, probably because of interspecific competition with flathead catfish for available prey resources. Native insectivores showed strong increases in biomass following increased exploitation. Native omnivores and the omnivore-collector group were predicted to increase following reductions in flathead biomass. Although neither of these groups competes directly with adult 

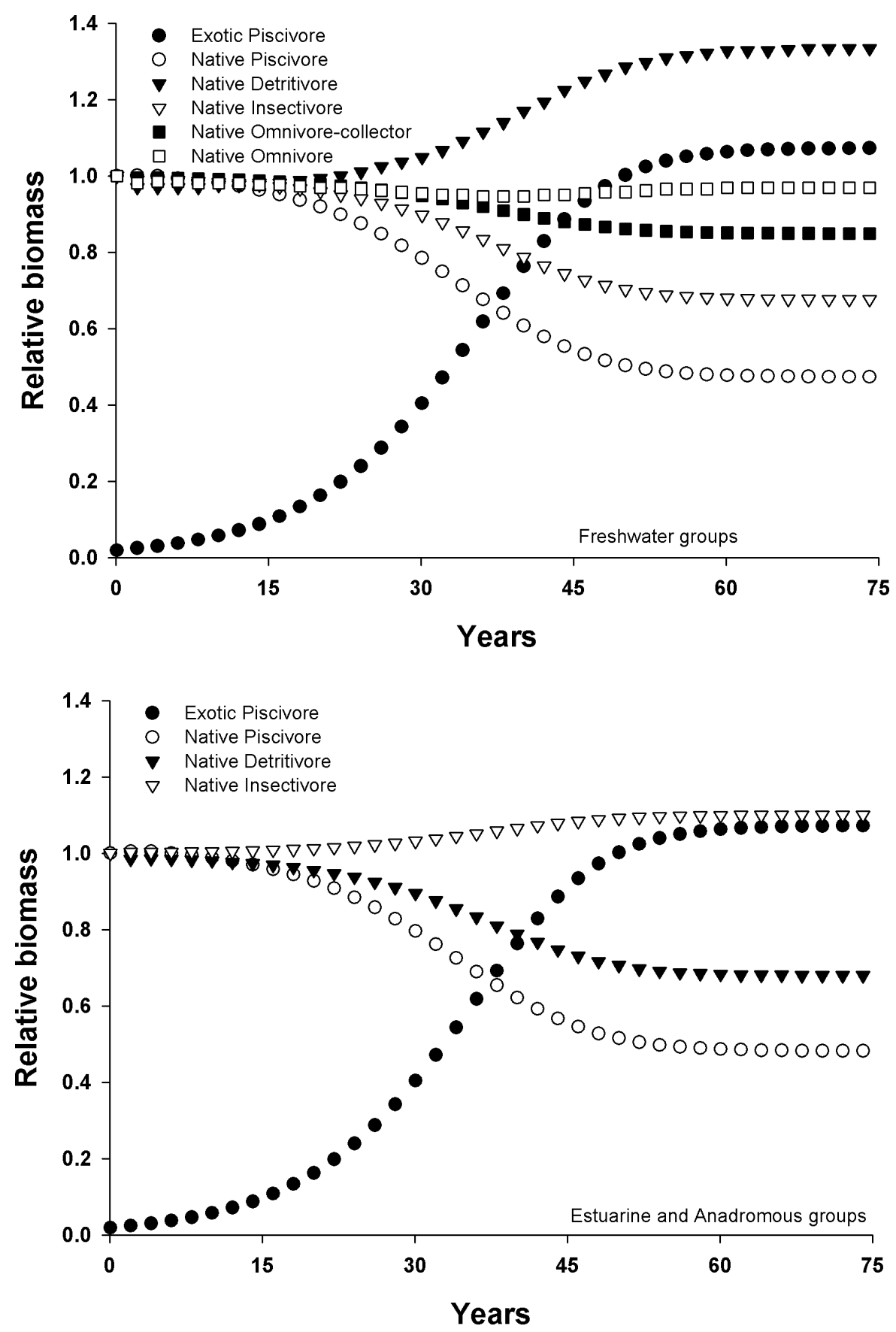

FIGURE 2.- Simulated ecosystem responses to the introduction of flathead catfish (exotic piscivore) in a coastal river by freshwater species (top panel) and estuarine and anadromous species (bottom panel) over a 75-year period. Responses are measured as the changes in the relative biomass of the various functional groups. The initial flathead catfish biomass in this simulation is that of the original North Carolina introduction (see text). 

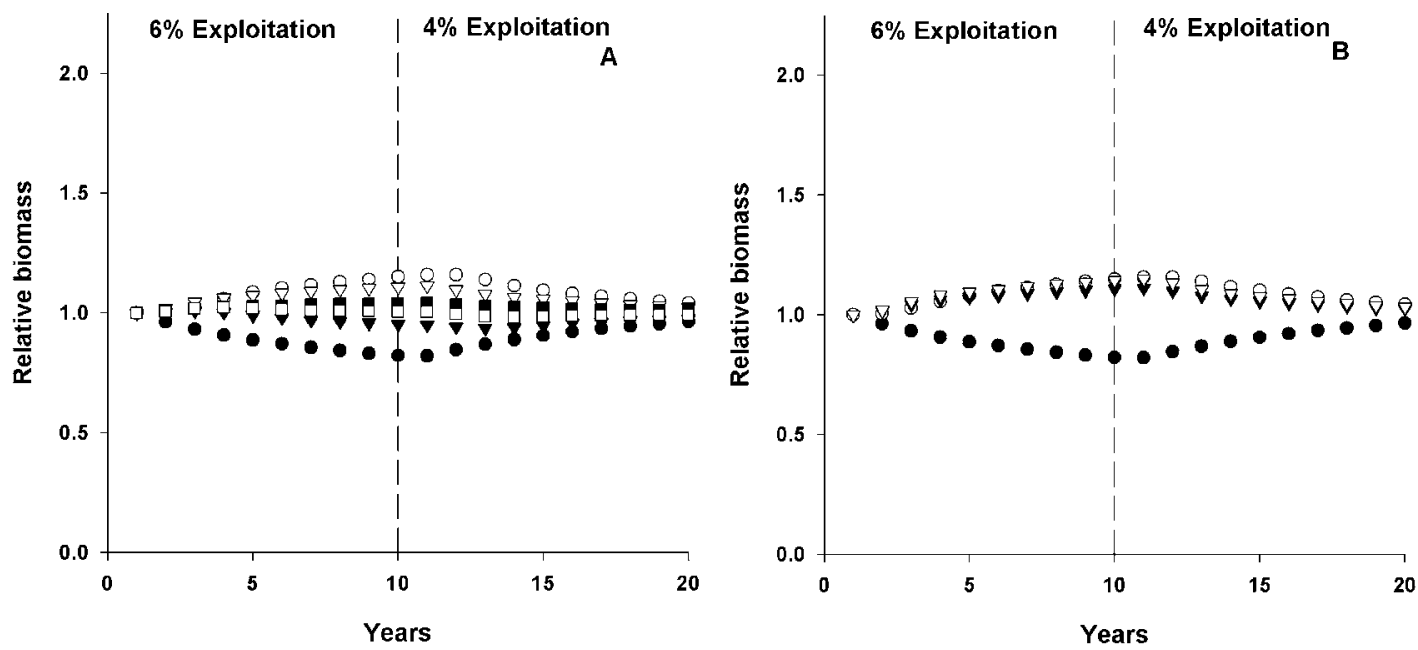

- Exotic Piscivore

- Native Piscivore

$\nabla$ Native Detritivore

$\nabla \quad$ Native Insectivore

- Native omnivore-grazer

$\square \quad$ Native omnivore
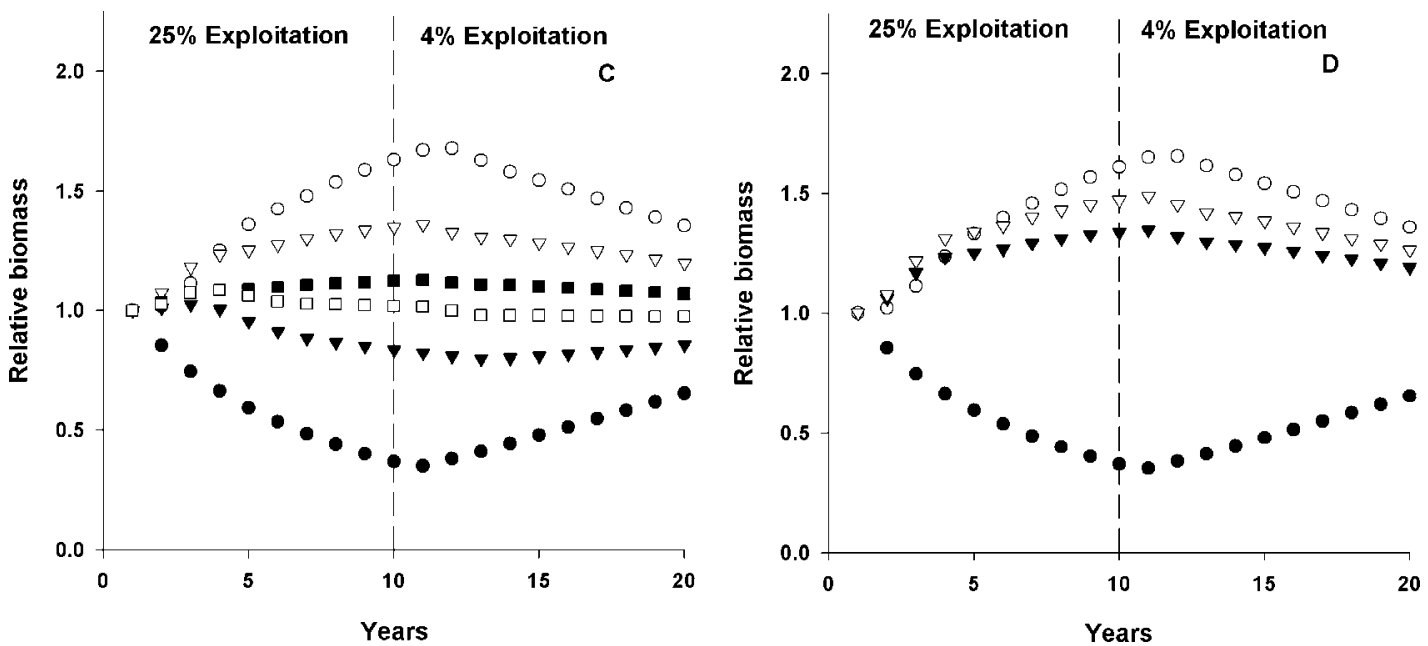

FIGURE 3.-Changes in the relative biomass of freshwater, anadromous, and estuarine fish groups in response to changes in flathead catfish (exotic piscivore) exploitation rates over a 20 -year period. The simulated exploitation rates of $6 \%$ (upper panels) and $25 \%$ (lower panels) encompass the range of reported flathead catfish exploitation rates for native and introduced populations. Each exploitation rate was applied for 10 years (areas to the left of the dashed vertical lines), and then exploitation was allowed to return to the current rate of $4 \%$ for 10 years (areas to the right of the dashed lines).

flathead catfish for food resources, they both comprise flathead catfish prey items. Thus, reduction in flathead catfish biomass reduces total mortality of these groups, thereby increasing biomass. The native omnivorecollector group consists of native darter and minnow species, groups that are sensitive to anthropogenic changes in aquatic environments. The additional mortality source on these groups imposed by an invasive predator could be particularly detrimental in an already stressed physical environment.

Two groups showed unexpected results associated with the declines in flathead catfish biomass. The estuarine group was composed primarily of hogchokers (90\%), and the unique body shape of this benthic 


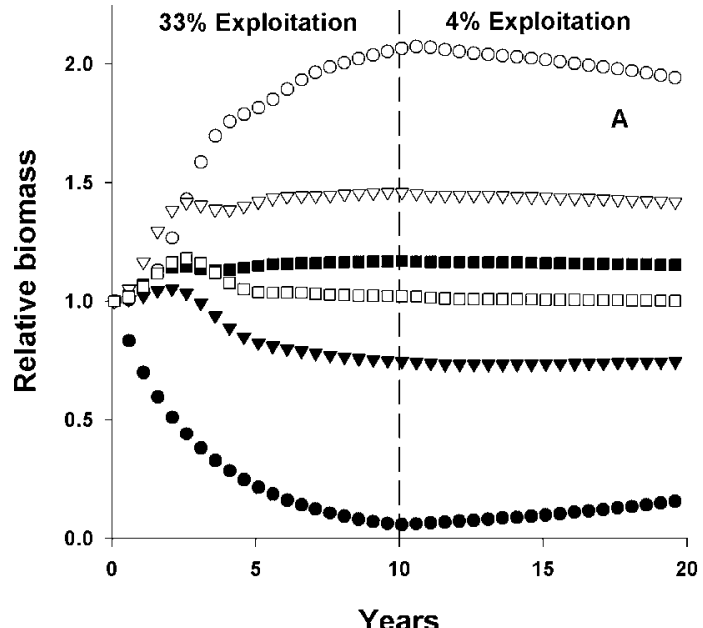

Years

- Exotic Piscivore

- Native Piscivore

$\checkmark$ Native Detritivore

$\nabla \quad$ Native Insectivore

- Native omnivorecollector

$\square \quad$ Native omnivore

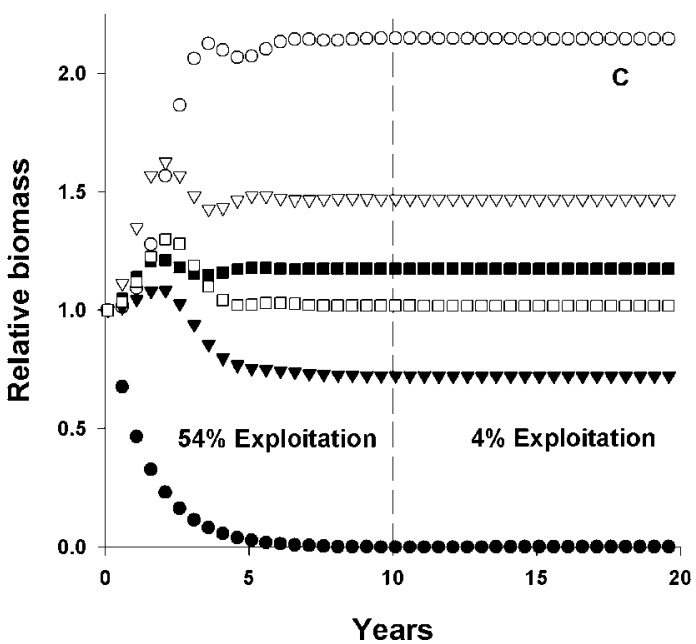

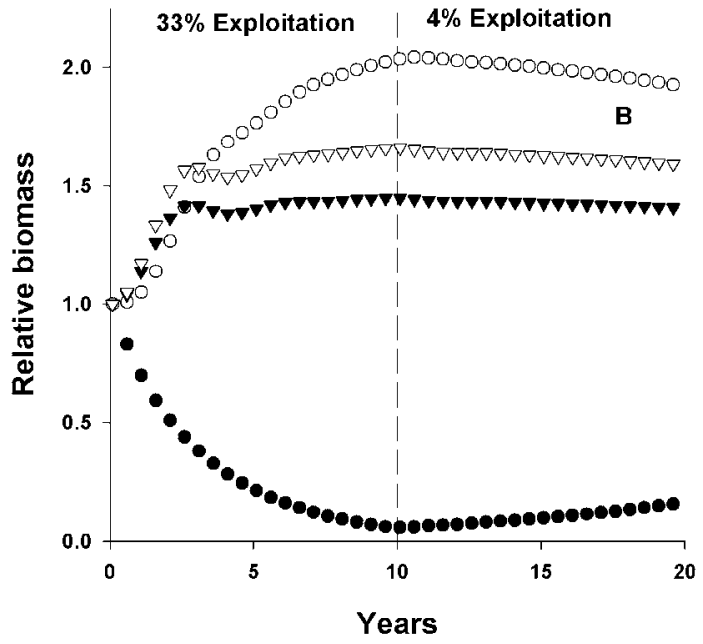

- Exotic Piscivore

- Anadromous Piscivore

- Anadromous Shad

$\nabla$ Estuarine

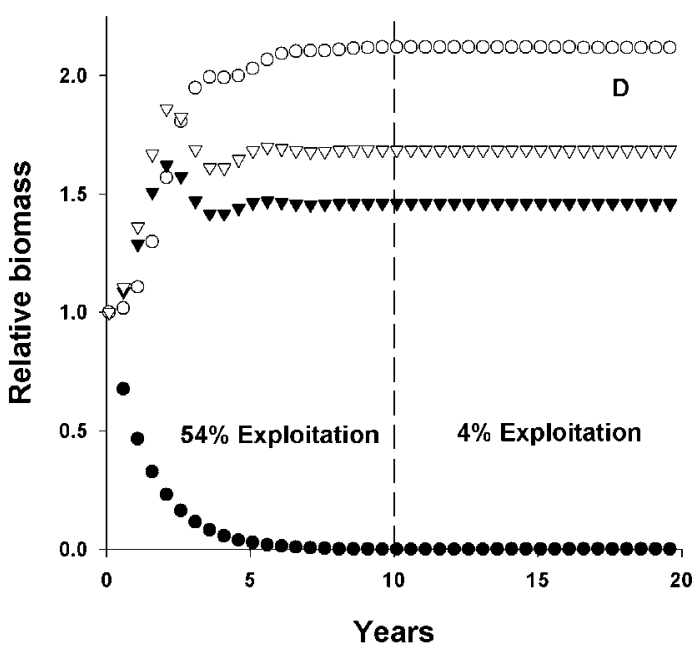

FIGURE 4.- Simulated ecosystem responses by freshwater, anadromous, and estuarine fish to attempts to eradicate flathead catfish (exotic piscivore) through intensive exploitation. Exploitation rates of 33\% and 54\% represent 10- and 20-fold increases from the current rate. Intensive exploitation was applied for 10 years (areas to the left of the dashed vertical lines), then exploitation was allowed to return to the current rate of $4 \%$ for 10 years (areas to the right of the dashed lines).

flatfish was easily identified in the flathead catfish diet samples. This may have led to an over-representation of hogchokers in the model diet matrix for flathead catfish, and coupled with their natural low biomass in the system, the hogchoker response to reductions in flathead catfish biomass may be exaggerated.

Native detritivores generally declined in biomass as exploitation rates increased for flathead catfish. The mechanism for these declines may be greater predation mortality on this group from the native and anadromous piscivore groups that were released from competition with flathead catfish. The native detritivore group included several redhorse species Moxostoma spp., a group in which corollary declines in abundance have been found in areas where flathead catfish have been introduced (Bart et al. 1994). 

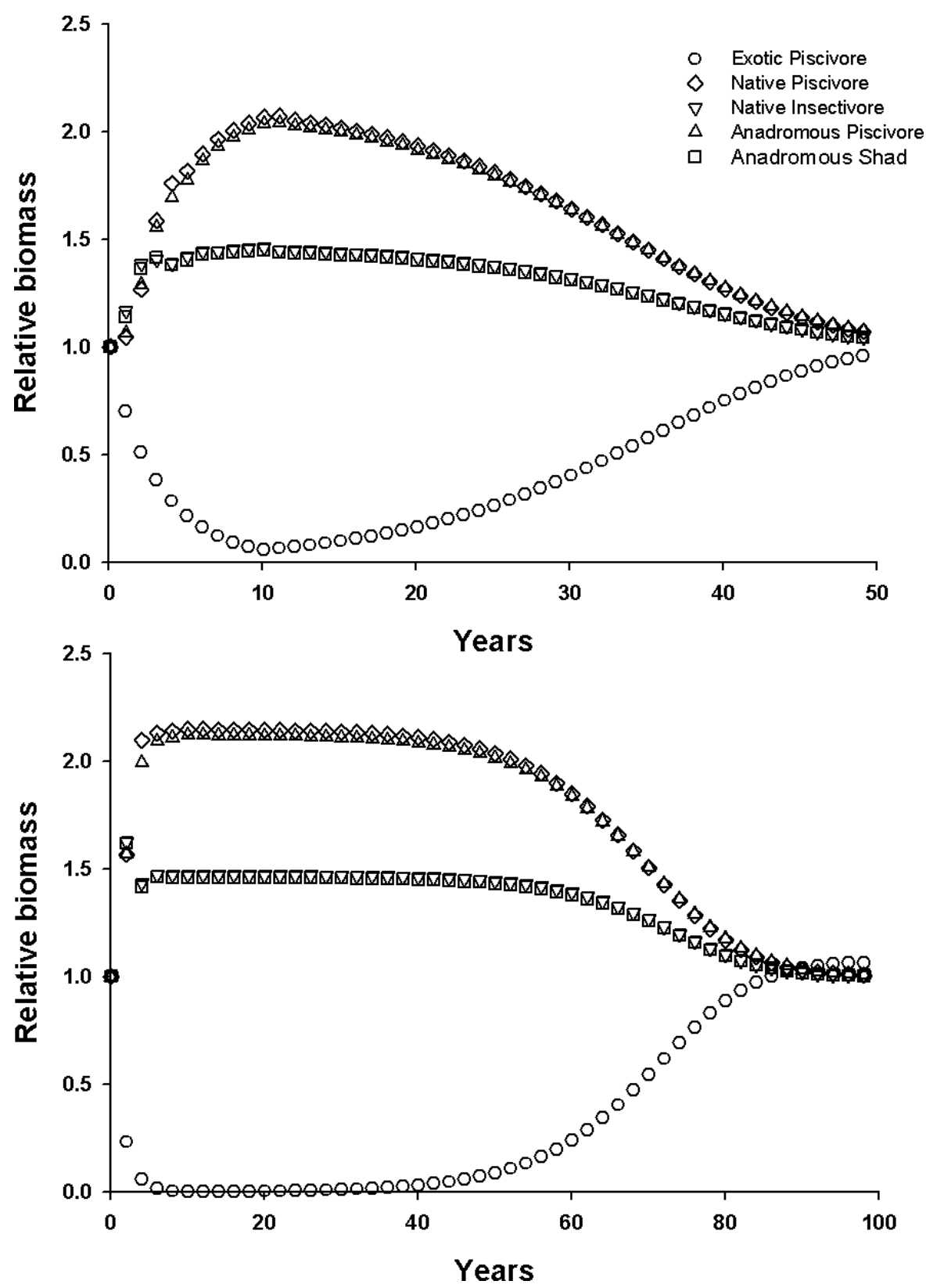

FIGURE 5.-Simulated resiliency of flathead catfish (exotic piscivore) populations to intensive exploitation. Flathead catfish were exploited at high rates (33\% in the top panel, $54 \%$ in the bottom panel) for 10 years and at $4 \%$ thereafter. Resiliency was measured in terms of the relative biomass of the population. Note that the duration of the simulation period ( $x$-axis) is different between the two panels.

Conversely, Guier et al. (1984) observed an increase in percent occurrence of redhorse species in the Cape Fear River following flathead catfish introduction. Our modeling efforts predict a decline in native detritivores, including redhorses, after flathead catfish introduction.

Restoration efforts for anadromous shad are current- ly underway in several rivers along the Atlantic Slope of the United States (Beasley and Hightower 2000; Limburg and Waldman 2003). Brown et al. (2005) documented the introduction and possible implications of flathead catfish in the Delaware and Susquehanna river drainages where more than $\$ 75$ million dollars 


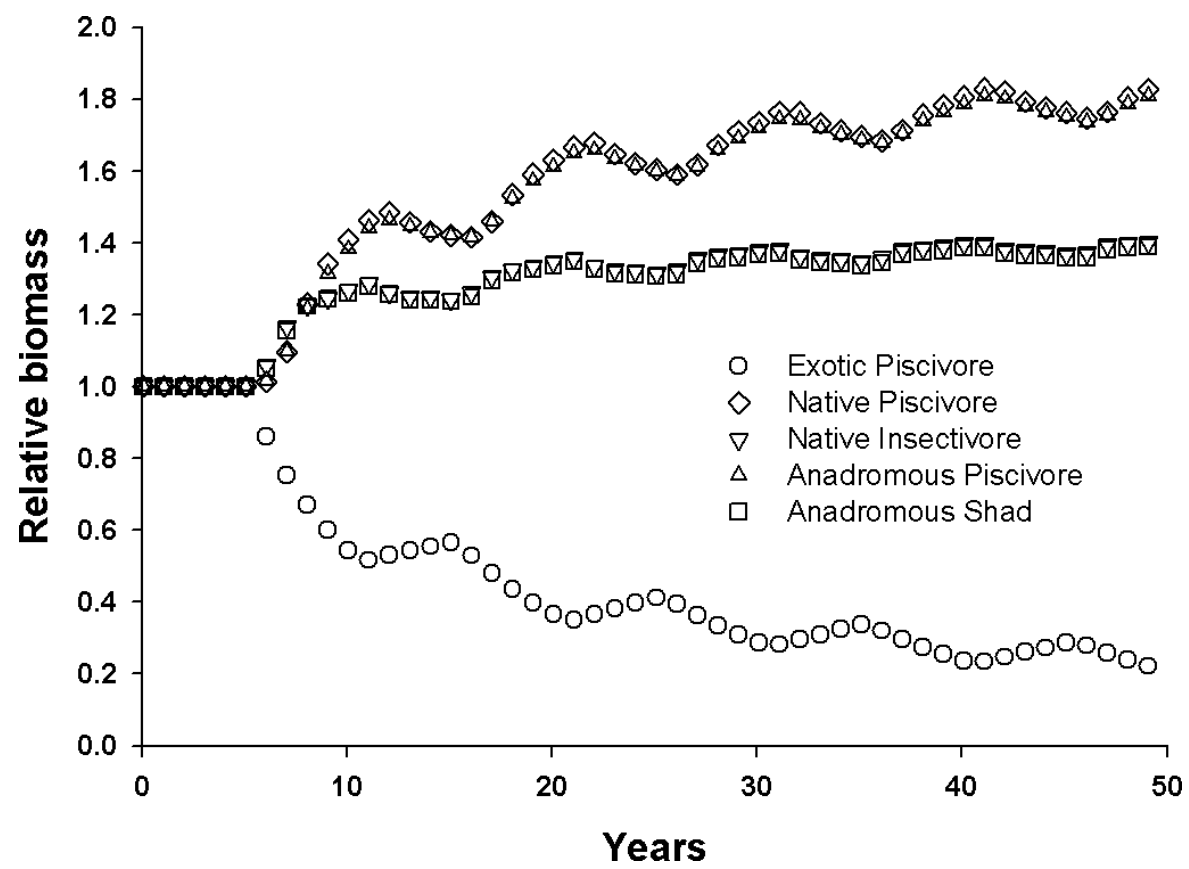

FIGURE 6.-Maintenance control simulation showing the responses of native fish group biomass to oscillating rates of flathead catfish (exotic piscivore) exploitation. Exploitation was held at the current rate (4\%) for 5 years after which it alternated between high $(25 \%)$ and low $(6 \%)$ rates for periods of 5 years for 45 years.

has been spent restoring anadromous shad species. Flathead catfish were first collected in this river system when adults of this species were found in fish ladders designed to aid anadromous fish migration as part of restoration programs for anadromous shad. Our model included a juvenile anadromous shad component from summer sampling of these fish before they emigrated to the ocean. The predicted increase in biomass for anadromous shad as flathead catfish exploitation increased is particularly important to these restoration efforts. In many fish species, growth and survival during early life can affect adult fish abundance (Houde 1987). Decreasing mortality at early life stages (such as juveniles) can potentially have large impacts on adult abundance. Resource managers should consider increased juvenile and adult predation mortality from invasive predators such as flathead catfish in designing restoration programs for anadromous shad species across the Atlantic Slope.

Complete elimination of flathead catfish is not feasible from Contentnea Creek or likely any coastal river where flathead catfish have become established. We documented flathead catfish migration from Contentnea Creek throughout most of the Neuse River basin (Kwak et al. 2004). Thus, the flathead catfish population is likely contiguous throughout the Neuse River basin, rather than consisting of smaller discrete population units, rendering eradication options unrealistic. Aquatic plant managers are accustomed to dealing with similar issues in designing control options for invasive aquatic plant species where efforts are directed at maintaining the population of the invasive species at the lowest feasible levels rather than complete eradication (Pieterse and Murphy 1990). By using maintenance control techniques to keep populations at low densities, less time and financial resources are expended by continuously harvesting populations, rather than by allowing populations to expand to large levels and then attempting to reduce them. Our maintenance control simulations demonstrate that this approach may be possible with invasive flathead catfish. In fact, the average population response for each native species group in the maintenance control scenario was at least twice as large as it would be from sustained harvest at the low level $(6 \%)$.

Apex predators are often the most successful invasive species (Moyle and Light 1996a, 1996b). This conclusion is based on theory and observations that prey species are usually highly vulnerable to the predation style of the newly introduced predator (Moyle and Light 1996a). In our model, the groups most strongly affected by changes in flathead catfish biomass were not species likely to be intensively preyed upon by flathead catfish (primarily native 
insectivores), but instead were groups competing with flathead catfish for available prey resources (native and anadromous piscivores). Coastal plain rivers in North Carolina are anthropogenically disturbed (Benniger and Wells 1993; Glasgow and Burkholder 2000) and relatively unproductive with low biomass of native fish species. Because of this low productivity in a disturbed environment competition for already limited available prey resources with an introduced predator dampens native and anadromous piscivore abundance.

The resilience of flathead catfish populations to fishing pressure is largely a function of the absence of any natural predator of this species. While several native piscivores in Contentnea Creek are also found in the native range of flathead catfish (e.g., largemouth bass), and these native predators likely feed on juvenile flathead catfish, this predation pressure is not intensive enough to suppress flathead catfish populations. This situation is similar to that of the cane toad Bufo marinus invasion in Australia where population densities of cane toads are often much higher in Australia than in native South American habitats (Lamp and De Leo 1998). The difference in population density between the two continents is primarily a function of higher adult survival in Australia due to a lack of cane toad predators, pathogens, and parasites.

\section{Model Limitations}

Although our simulations suggest that reducing flathead catfish biomass by increasing exploitation could release most native fish groups from competition and predation pressures, thereby leading to increased biomass, several issues should be considered in evaluating these results. We examined changes in population biomass of a variety of fish groups in response to exploitation of flathead catfish, which resulted in subsequent changes in other components of the ecosystem through changes in predation mortality or resource competition with other groups. One issue with ecosystem models is that they, like many models, are difficult to validate, which may lead some people to question their utility in screening policy scenarios. The similarity between our model predictions and those observed in the field by Guier et al. (1984) and other empirical observations is expected and serves as a means to examine the realism of our model.

A key goal in developing the Ecopath framework is to enhance the capability to ask policy questions that cannot be addressed in more traditional single-species assessment models. A common concern with ecosystem models is that because we never have enough information to develop a perfect model at the individual level, how can we build a useful model at the ecosystem level? The Ecopath framework links the pieces of information that are available into a common framework and allows us to examine how these pieces of information fit together. In our case we drew information from our own field studies, published records, observations by experienced fisheries biologists in the region, and agency reports to assemble a picture of how a coastal North Carolina river system functioned. When assembled within an Ecopath framework (which has been examined and tested in a wide variety of systems), the assembled pieces provided a useful platform to examine policy scenarios related to flathead catfish management. This platform also helped to serve as a guide to future research by identifying critical information gaps in native fish ecology in coastal Atlantic Slope rivers.

We did not evaluate how changes in the size structure of populations within each of the functional groups would change in response to lower flathead catfish biomass. For example, flathead catfish exploitation may reduce the number of large individuals in the population, which would restructure the population into one dominated by small individuals. These smaller individuals may have greater physiological energetic demands than the larger individuals that were removed from the population. We calculated functional group biomass using average weight values for individual species. These averages could bias the biomass for all functional groups, but the proportional relationships between functional groups likely remain reasonably accurate.

We used a three-pass removal method to generate abundance estimates of the species in each of our functional groups. Removal estimates generally do not account for heterogeneity in capture probability, which can lead to an underestimate in population size (Peterson et al. 2004). This underestimate in population size could lead to exaggerated effects of flathead catfish predation on native fish functional groups and imprecise or inaccurate predictions of possible management actions related to flathead catfish removal programs. However, like any modeling exercise, our model is designed to provide guidance to help screen and explore policy and management scenarios. While the model itself is completely dependent on the input values, we suggest that our input values are sufficiently precise to generate a realistic representation of the ecosystem linkages within a coastal North Carolina river.

Our model assumes constant recruitment of all fish species. Allen and Pine (2000) showed that changes in population biomass from altering exploitation rates could be masked by variable recruitment in 3- or 5-year study periods for largemouth bass and white crappie Pomoxis annularis. Recruitment variability is typical of 
nearly all fish species; thus, changes in biomass for any species may be expedited in years following low recruitment or delayed in years following high recruitment. Our simulated manipulation of flathead catfish biomass by altering mortality rates affects total mortality of all other species in the food web by changing predation mortality and competition. Thus, variable recruitment could change the dynamics and rate at which various components of the ecosystem respond to flathead catfish exploitation.

Our model was developed with information collected from an ecosystem that may have already been altered by the invasion of flathead catfish. The current fish assemblage in Contentnea Creek may suffer from the effects of predation that occurred in the past such that any potential impact to native species by the exotic may have occurred before this study. It is possible that flathead catfish have extirpated species from Contentnea Creek or reduced population densities below detectable levels. Obviously, these species would not be included in our model and the interaction between species that no longer exist and other components of the ecosystem cannot be evaluated with typical modeling approaches. Our model is based on the current conditions within the ecosystem, which include the effects of flathead catfish. By manipulating flathead catfish biomass and examining the population release in the native community based on current conditions, we are not basing predictions on riverine conditions before the flathead catfish introduction for which we have little or no information.

\section{Management Implications}

Our modeling results suggest that moderate, sustained levels of flathead catfish exploitation may release native fish groups from predation by and competition with flathead catfish. This finding is important for resource managers involved in restoring native fish populations in areas where flathead catfish have been introduced. Management agencies could promote harvest of flathead catfish populations by offering a bounty or subsidy system to commercial fishers in an effort to establish an interest in harvesting this species (by guaranteeing an attractive price) and simultaneously developing a market for the fish product. Increasing the size and intensity of the recreational fishery is an equally important aspect of any effort to reduce flathead catfish biomass and provide sustained fishing pressure. Schramm et al. (1999) found that Mississippi catfish anglers preferred to fish in rivers and streams and that anglers found it very important to keep a lot of fish, leading those authors to note that "increased fishing effort and high harvest could deplete these (catfish) resources."
We found that flathead catfish exploitation rates in native systems $(25 \%)$ would be more than adequate to provide a large $(>30 \%)$ increase in most native fish groups. However, this level of exploitation would not likely be sustainable in the rivers we studied, leading to overexploitation of the flathead catfish population, and subsequent declines in catch rates and a loss of participants in the fishery. Given the resiliency of flathead catfish populations to exploitation, the predicted benefits to native fish groups are only achievable if flathead catfish fishing pressure is sustained to some degree. Declines in exploitation would allow flathead catfish populations to return to preexploitation levels, thereby losing the benefits realized in the native fish communities while flathead catfish populations were suppressed.

Both modeling exercises and empirical data include error, and many models may be unreliable for quantitative predictions (Johnson 1995) but are often well suited to screening policy options (e.g., Ecopath; Christensen and Walters 2004). Models such as the one we used are useful for examining trends in ecosystem dynamics, possibly providing some insight into the complex and cascading effects of an invasive species on coastal riverine ecosystems and direction for future flathead catfish management. Given the improbability of controlled replicated field studies involving invasive species, a modeling approach such as this may be the most reasonable means to elucidate species interactions from an ecological perspective.

Our simulation results suggesting positive responses in native fish biomass after flathead catfish harvest could be considered as a part of a broader ecosystem restoration effort to mitigate the variety of anthropogenic ecosystem alterations in coastal rivers. While many aspects of aquatic ecosystem restoration remain in an experimental phase (Lenihan et al. 1999), our ability to harvest fish populations is well established, and directed harvest of flathead catfish may represent a conceptually simple but important step in helping restore native ecosystems.

\section{Acknowledgments}

We thank K. Pollock, J. Hightower, R. Noble, C. Walters and H. Li for comments on an earlier draft of this manuscript and J. Buckle for assistance in model development. K. Ashley, D. Dutterer, E. Malindzak, T. Rachels, C. Waters, and S. Waters all provided assistance with data collection and technical insight. This research was supported by a grant from the North Carolina Wildlife Resources Commission through Federal Aid in Sport Fish Restoration Funds (Project F-68). 


\section{References}

Allen, M. S., and W. E. Pine, III. 2000. Detecting fish population responses to a minimum length limit: effects of variable recruitment and duration of evaluation. North American Journal of Fisheries Management 20:672-682.

Ashley, K. W., and B. Buff. 1988. Food habits of flathead catfish in the Cape Fear River, North Carolina. Proceedings of the Annual Conference Southeastern Association of Fish and Wildlife Agencies 41(1987):9399.

Bart, H. L., M. S. Taylor, J. T. Harbaugh, J. W. Evans, S. L. Schleiger, and W. Clark. 1994. New distribution records of Gulf Slope drainage fishes in the Ocmulgee River system, Georgia. Southeastern Fishes Council Proceedings. 30:4-9.

Beasley, C. A., and J. E. Hightower. Effects of a low-head dam on the distribution and characteristics of spawning habitat used by striped bass and American shad. Transactions of the American Fisheries Society 129:1316-1330.

Benniger, L. K., and J. T. Wells. 1993. Sources of sediment to the Neuse River estuary, North Carolina. Marine Chemistry 43:127-156.

Brown, J. J., J. Perillo, T. J. Kwak, and R. J. Horwitz. 2005. Implications of Pylodictis olivaris (flathead catfish) introduction into the Delaware and Susquehanna drainages. Northeastern Naturalist 12:473-484.

Christensen, V., C. J. Walters, and D. Pauly. 2000. Ecopath with Ecosim: a user's guide. Fisheries Centre, University of British Columbia, Research Report Series, Vancouver.

Christensen, V., and C. J. Walters. 2004. Ecopath with Ecosim: methods, capabilities, and limitations. Ecological Modelling 172:109-139.

Elton, C. S. 1958. The ecology of invasions of plants and animals. University of Chicago Press, Chicago.

Folkerts, G. W. 1999. State and fate of the world's aquatic fauna. Pages 1-16 in G. W. Benz and D. E. Collins, editors. Aquatic fauna in peril: the southeastern perspective. Southeastern Aquatic Research Institute, Special Publication Number 1, Decatur, Georgia.

Glasgow, H. B., and J. J. Burkholder. 2000. Water quality trends and management implications from a five-year study of a eutrophic estuary. Ecological Applications 10:1024-1046.

Guier, R. C., L. E. Nichols, and R. T. Rachels. 1984. Biological investigation of flathead catfish in the Cape Fear River. Proceedings of the Annual Conference Southeastern Association of Fish and Wildlife Agencies 35(1981):607-621.

Houde, E. D. 1987. Fish early life dynamics and recruitment variability. Pages 17-29 in R. D. Hoyt, editor. 10th Annual larval fish conference. American Fisheries Society, Symposium 2, Bethesda, Maryland.

Jackson, D. C. 1999. Flathead catfish: biology and management. Pages 23-36 in E. R. Irwin, W. A. Hubert, C. F. Rabeni, H. L. Schramm, Jr., and T. Coon, editors. Catfish 2000: proceedings of the International Ictalurid Symposium. American Fisheries Society, Symposium 24, Bethesda, Maryland.

Jackson, J. B. C., M. X. Kirby, W. H. Berger, K. A. Bjorndal, L. W. Botsford, B. J. Bourque, R. H. Bradbury, R. Cooke, J. Erlandson, J. A. Estes, T. P. Hughes, S.
Kidwell, C. B. Lange, H. S. Lenihan, J. M. Pandolfi, C. H. Peterson, R. S. Steneck, M. J. Tegner, and R. R. Warner. 2001. Historical overfishing and the recent collapse of coastal ecosystems. Science 293:629-638.

Jenkins, R. E., and N. M. Burkhead. 1994. Freshwater fishes of Virginia. American Fisheries Society, Bethesda, Maryland.

Johnson, B. L. 1995. Applying computer simulation models as learning tools in fishery management. North American Journal of Fisheries Management 15:736-747.

Kitchell, J. F., S. P. Cox, C. J. Harvey, T. B. Johnson, D. M. Mason, K. K. Shoen, K. Aydin, C. Bronte, M. Ebner, M. Hansen, M. Hoff, S. Schram, D. Schreiner, and C. J. Walters. 2000. Sustainability of the Lake Superior fish community: interactions in a food web context. Ecosystems 3:545-560.

Krebs, C. J., K. Danell, A. Angerbjörn, J. Agrell, D. Berteaux, K. A. Bråthen, Ö. Danell, S. Erlinge, V. Fedorov, K. Fedga, J. Hjältén, G. Högstedt, I. S. Jóngdóttir, A. J. Kenney, N. Kjellén, T. Nordin, J. Roininen, M. Svensson, M. Tannerfeldt, and C. Wiklund. 2003. Terrestrial trophic dynamics in the Canadian Arctic. Canadian Journal of Zoology 81:827-843.

Kwak, T. J., W. E. Pine, III, and D. S. Waters. 2006. Age, growth, and mortality of introduced flathead catfish in Atlantic rivers and a review of other populations. North American Journal of Fisheries Management 26:73-87.

Kwak, T. J., W. E. Pine, III, D. S. Waters, J. A. Rice, J. E. Hightower, and R. L. Noble. 2004. Population dynamics and ecology of introduced flathead catfish: phase 1 . North Carolina Wildlife Resources Commission, Federal Aid in Sport Fish Restoration, Project F-68, Study 1, Final Report, Raleigh.

Lampo, M., and G. A. De Leo. 1998. The invasion ecology of the toad Bufo marinus: from South America to Australia. Ecological Applications 8:388-396.

Lenihan, H. S., F. Micheli, S. W. Shelton, and C. H. Peterson. 1999. The influence of multiple environmental stressors on susceptibility to parasites: an experimental determination with oysters. Limnology and Oceanography 44:910-924.

Li, H. W., and P. B. Moyle. 1993. Management of introduced fishes. Pages 287-308 in C. C. Kohler and W. A. Hubert, editors. Inland fisheries management in North America. American Fisheries Society, Bethesda, Maryland.

Limburg, K. E., and J. R. Waldman, editors. 2003. Biodiversity, status, and conservation of the world's shads. American Fisheries Society, Symposium 35, Bethesda, Maryland.

Marsh, P. C., and J. E. Brooks. 1989. Predation by ictalurid catfishes as a deterrent to reestablishment of hatcheryreared razorback suckers. Southwestern Naturalist 34:188-195.

Moyle, P. B., and T. Light. 1996a. Biological invasions of freshwater: empirical rules and assembly theory. Biological Conservation 78:149-161.

Moyle, P. B., and T. Light. 1996b. Fish invasions in California: do abiotic factors determine success? Ecology 77:1666-1670.

Nielsen, L. A. 1993. History of inland fisheries management in North America. Pages 3-28 in C. C. Kohler and W. A. Hubert, editors. Inland fisheries management in North 
America, 2nd edition. American Fisheries Society, Bethesda, Maryland.

Palomares, M. L., and D. Pauly. 1989. A multiple-regression model for predicting the food consumption of marine fish populations. Australian Journal of Marine and Freshwater Research 40:259-273.

Pauly, D. 1986. A simple method for estimating the food consumption of fish populations from growth data and food conversion experiments. U.S. National Marine Fisheries Service Fishery Bulletin 84:827-839.

Peterson, J. T., R. F. Thurow, and J. Guzevich. 2004. An evaluation of multi-pass electrofishing for estimating the abundance of stream-dwelling salmonids. Transactions of the American Fisheries Society 133:462-475.

Pieterse, A. H., and K. J. Murphy. 1990. Aquatic weeds: the ecology and management of nuisance aquatic vegetation. Oxford University Press, Oxford, UK.

Pimentel, D., L. Lach, R. Zuniga, and D. Morrison. 2000. Environmental and economic cost of nonindigenous species in the United States. BioScience 50:53-65.

Pine, W. E., III. 2003. Population ecology of introduced flathead catfish. Doctoral dissertation. North Carolina State University, Raleigh.

Pine, W. E., III, T. J. Kwak, D. S. Waters, and J. R. Rice. 2005. Diet selectivity of introduced flathead catfish in coastal rivers. Transactions of the American Fisheries Society 134:901-909.

Quinn, S. P. 1988. Stomach contents of flathead catfish in the Flint River, Georgia. Proceedings of the Annual Conference Southeastern Association of Fish and Wildlife Agencies 41(1987):85-92.

Quinn, S. P. 1993. Description of a multiple-use fishery for flathead catfish. North American Journal of Fisheries Management 13:594-599.

Rahel, F. J. 2000. Homogenization of fish faunas across the United States. Science 288:854-856.

Schramm, H. L., Jr., J. T. Forbes, D. A. Gill, and W. D. Hubbard. 1999. Fishing environment preferences and attitudes toward overharvest: are catfish anglers unique? Pages 417-426 in E. R. Irwin, W. A. Hubert, C. F. Rabeni, H. L. Schramm, Jr., and T. Coon, editors. Catfish 2000: proceedings of the International Ictalurid Symposium. American Fisheries Society, Symposium 24, Bethesda, Maryland.

Seber, G. S. 1982. The estimation of animal abundance and other parameters. Macmillan, New York.

Smith-Vaniz, W. F. 1968. Freshwater fishes of Alabama. Paragon Press, Montgomery, Alabama.

Swingle, H. S. 1967. Experiments with the flathead catfish (Pylodictis olivaris) in ponds. Proceedings of the Annual Conference Southeastern Association of Game and Fish Commissioners 18(1964):303-308.

Thomas, M. E. 1995. Monitoring the effects of introduced flathead catfish on sport fish populations in the Altamaha River, Georgia. Proceedings of the Annual Conference Southeastern Association of Fish and Wildlife Agencies 47(1993):531-538.

Travnichek, V. H., and H. D. Clemmons. 2001. Utility of tournament data for assessing effects of eliminating commercial catfish harvest in the Missouri River. North American Journal of Fisheries Management 21:688-691.

USDOI (U.S. Department of the Interior). 2005. Fiscal year 2005: the Interior budget in brief. USDOI, Washington, D.C. (www.doi.gov/budget/2005/05Hilites/toc.html).

Vander Zanden, M. J., J. D. Olden, J. H. Thorne, and N. E. Mandrak. 2004. Predicting occurrences and impacts of smallmouth bass introductions in north temperate lakes. Ecological Applications 14:132-138.

Walters, C. J., V. Christensen, and D. Pauly. 1997. Structuring dynamic models of exploited ecosystems from trophic mass-balance assessments. Reviews in Fish Biology and Fisheries 7:1-37.

Waters, T. F. 1977. Secondary production in inland waters. Advances in Ecological Research 10:91-164.

Williamson, M. 1996. Biological invasions. Chapman and Hall, London. 


\section{Appendix: Input Data for the Ecopath Model}

TABLE A.1.-Parameter estimates used in the mass-balance Ecopath model. See Table 1 in the text for the precise composition of each functional group.

\begin{tabular}{lccc}
\hline Functional group & $\begin{array}{c}\text { Biomass } \\
\left.\text { (tons/km }{ }^{2}\right)^{\mathrm{a}}\end{array}$ & $\begin{array}{c}\text { Production/ } \\
\text { biomass }^{\mathrm{b}}\end{array}$ & $\begin{array}{c}\text { Consumption/ } \\
\text { biomass }^{\mathrm{c}}\end{array}$ \\
\hline Exotic piscivore & 0.237 & 0.150 & 3.600 \\
Native piscivore & 0.165 & 1.050 & 3.930 \\
Native detritivore & 0.022 & 1.750 & 14.100 \\
Native insectivore & 0.185 & 2.800 & 10.000 \\
Native omnivore collector & 0.390 & 1.890 & 36.700 \\
Native omnivore & 0.025 & 1.750 & 4.800 \\
Anadromous piscivore & 0.003 & 2.000 & 6.000 \\
Anadromous shad & 0.035 & 2.200 & 5.000 \\
Estuarine & 0.015 & 2.600 & 10.000 \\
Invertebrates & 4.000 & 5.500 & 16.500 \\
Plankton & 1.000 & 35.000 & \\
Detritus & 100.000 & &
\end{tabular}

\footnotetext{
a Sources: Pine (2003) except for invertebrates (Waters 1977) and plankton and detritus (literature).

b Sources: Pine (2003; multiple three-pass removals) except for exotic piscivore (Pine 2003; catch curve), invertebrates (Waters 1977), and plankton (literature). Values are per year.

c Sources: Fishbase (www.fishbase.org) and Pine (2003). Values are per year.
}

TABle A.2.-Diet composition (\%) for each functional group used in the Ecopath model. The information for the exotic piscivore functional group is from diet samples collected in Pine (2003); that for other groups is derived from the literature.

\begin{tabular}{|c|c|c|c|c|c|c|c|c|c|c|c|c|}
\hline & $\begin{array}{l}\text { Exotic } \\
\text { pisci- } \\
\text { vore }\end{array}$ & $\begin{array}{c}\text { Native } \\
\text { pisci- } \\
\text { vore }\end{array}$ & $\begin{array}{c}\text { Native } \\
\text { detriti- } \\
\text { vore }\end{array}$ & $\begin{array}{c}\text { Native } \\
\text { insecti- } \\
\text { vore }\end{array}$ & $\begin{array}{l}\text { Native } \\
\text { omnivore- } \\
\text { collector }\end{array}$ & $\begin{array}{c}\text { Native } \\
\text { omni- } \\
\text { vore }\end{array}$ & $\begin{array}{l}\text { Anad- } \\
\text { romous } \\
\text { piscivore }\end{array}$ & $\begin{array}{l}\text { Anad- } \\
\text { romous } \\
\text { shad }\end{array}$ & $\begin{array}{c}\text { Estuarine } \\
\text { species }\end{array}$ & $\begin{array}{c}\text { Inverte- } \\
\text { brates }\end{array}$ & Plankton & Detritus \\
\hline Exotic piscivore & 0.0 & 0.4 & 0.4 & 35.0 & 31.0 & 1.2 & 0.0 & 5.0 & 2.5 & 24.5 & 0.0 & 0.0 \\
\hline Native piscivore & 0.0 & 10.0 & 5.0 & 27.5 & 20.0 & 5.0 & 0.0 & 5.0 & 2.5 & 25.0 & 0.0 & 0.0 \\
\hline Native detritivore & 0.0 & 0.0 & 0.0 & 0.0 & 0.0 & 0.0 & 0.0 & 0.0 & 0.0 & 0.0 & 0.0 & 100.0 \\
\hline Native insectivore & 0.0 & 0.0 & 0.0 & 0.0 & 0.0 & 0.0 & 0.0 & 0.0 & 0.0 & 50.0 & 40.0 & 10.0 \\
\hline Native omnivore-collector & 0.0 & 0.0 & 0.0 & 0.0 & 0.0 & 0.0 & 0.0 & 0.0 & 0.0 & 40.0 & 40.0 & 20.0 \\
\hline Native omnivore & 0.0 & 0.0 & 0.0 & 5.0 & 5.0 & 0.0 & 0.0 & 0.0 & 0.0 & 50.0 & 0.0 & 40.0 \\
\hline Anadromous piscivore & 0.0 & 0.0 & 10.0 & 25.0 & 35.0 & 5.0 & 0.0 & 0.0 & 5.0 & 20.0 & 0.0 & 0.0 \\
\hline Anadromous shad & 0.0 & 0.0 & 0.0 & 0.0 & 0.0 & 0.0 & 0.0 & 0.0 & 0.0 & 0.0 & 80.0 & 20.0 \\
\hline Estuarine species & 0.0 & 0.0 & 0.0 & 0.0 & 20.0 & 0.0 & 0.0 & 0.0 & 0.0 & 40.0 & 10.0 & 30.0 \\
\hline Invertebrates & 0.0 & 0.0 & 0.0 & 0.0 & 0.0 & 0.0 & 0.0 & 0.0 & 0.0 & 0.0 & 0.0 & 100.0 \\
\hline
\end{tabular}

